\title{
Tumor Necrosis Factor-Alpha Stimulates Hepatic Lipogenesis in the Rat In Vivo
}

\author{
Kenneth R. Feingold and Carl Grunfeld
}

With the technical assistance of Arthur H. Moser, Steven R. Lear, and Bao-Jun Huang

Department of Medicine, University of California at San Francisco, San Francisco, California 94143; and Metabolism Section (111F), Veterans Administration Medical Center, San Francisco, California 94121

\begin{abstract}
The hyperlipidemia accompanying infection has been attributed to production of tumor necrosis factor. This cytokine inhibits adipose tissue lipoprotein lipase, which could decrease clearance of lipoproteins. Infections also increase hepatic lipogenesis. We now have demonstrated that tumor necrosis factor-alpha stimulattes lipid synthesis in vivo. $2 \mathrm{~h}$ after administration of tumor nécrosis factor $(25 \mu \mathrm{g} / 200 \mathrm{~g})$, plasma triglycerides increase 2.2fold and remain elevated for $17 \mathrm{~h}$. Plasma cholesterol also increases, but this effect appears after $7 \mathrm{~h}$. Tumor necrosis factor rapidly stimulates incorporation of tritiated water into fatty acids in the liver (1-2 h), which persists for $17 \mathrm{~h}$. Also, tumor necrosis factor stimulates hepatic sterol synthesis. Of note, tumor necrosis factor treatment does not stimulate lipid synthesis in other tissues, including adipose tissue. Labeled fatty acids rapidly increase in the plasma, raising the possibility that stimulation of hepatic lipógenesis by tumor necrosis factor contributes to the hyperlipidemia of infection.
\end{abstract}

\section{Introduction}

İnfection by microorganisms elicits a complex host response that results in the killing and removal of the infectious agents as well as providing immunity against future challenges. This response involves multiple cell types and is modulated by cytokines (13): The observation that serum from animals treated with endotoxin contained proteins that caused the hemorrhagic necrosis of tumors led to the discovery of tumor necrosis factor (TNF), ${ }^{1}$ a cytokine produced by stimulated macrophages which has been shown to be toxic to a variety of malignant cells $(4,5)$.

Disturbances in intermediary metabolism may also occur with infection (6). Hyperlipidemia, primarily due to the accumulation of very low density lipoprotein (VLDL), is one such metabolic aberration $(7,8)$. Studies have shown that in infectious diseases there is both a decrease in the metabolism of circulating lipoproteins (9) and an increase in hepatic lipid synthesis (10). Cerami and co-workers have demonstrated that endotoxinstimulated mouse macrophages secrete a factor, which they called cachectin, that decreases the synthesis and storage of lipid in

Address all correspondence to Dr. Kenneth R. Feingold, Veterans Administration Medical Center, Metabolism Section (111F), 4150 Clement Street, San Francisco, CA 94121.

Received for publication 2 September 1986.

1. Abbreviations used in this paper: HMG CoA, 3-hydroxy-3-methylglutaryl coenzyme A; TNF, tumor necrosis factor.

J. Clin. Invest.

(C) The American Society for Clinical Investigation, Inc.

0021-9738/87/07/0184/07 \$2.00

Volume 80, July 1987, 184-190 cultured fat cells $(11,12)$. After purification cachectin was shown to be identical to mouse TNF by amino acid sequence analysis (13). This cytokine decreases the activity of adipose tissue lipoprotein lipase, an effect that is due to the decreased synthesis of the enzyme (12). A decrease in lipoprotein lipase activity could lead to a decreased clearance from the circulation of triglyceriderich lipoproteins, such as VLDL, and thereby result in hyperlipidemia. Thus, the hyperlipidemia that accompanies infection could be mediated by the TNF inhibition of adipose tissue lipoprotein lipase activity. Whether TNF has additional effects that also contribute to the hyperlipidemia is unknown.

Despite the considerable data on the effect of TNF on cultured adipose cells, the effect of TNF on lipid metabolism in other tissues has not been studied. In particular, the effect of TNF on lipid synthesis in the liver, the key organ in the regulation of total body lipid metabolism, has not been examined. We demonstrate that the administration of TNF to intact animals stimulates hepatic lipid synthesis.

\section{Methods}

Materials. ${ }^{3} \mathrm{H}_{2} \mathrm{O}(1 \mathrm{Ci} / \mathrm{g})$ was purchased from ICN Radiochemicals, Div. ICN Biochemicals Inc., Irvine, CA. $1-\left[{ }^{14} \mathrm{C}\right]$ Sodium acetate $(56.2 \mathrm{mCi}$ / $\mathrm{mmol}), 1,2\left[{ }^{3} \mathrm{H}\right]$ cholesterol $(31 \mathrm{Ci} / \mathrm{mmol}), 26\left[{ }^{14} \mathrm{C}\right]$ cholesterol $(0.5 \mathrm{mCi} /$ $0.33 \mathrm{mg}$ ), $3\left[{ }^{14} \mathrm{C}\right] 3$-hydroxy-3-methylglutaryl coenzyme A (HMG CoA) $(40-60 \mathrm{mCi} / \mathrm{mmol}),\left[{ }^{3} \mathrm{H}\right]$ oleic acid $(2-10 \mathrm{Ci} / \mathrm{mmol}),\left[{ }^{14} \mathrm{C}\right]$ oleic acid $(40-$ $60 \mathrm{mCi} / \mathrm{mmol})$, and $\mathrm{RS} 5\left[^{3} \mathrm{H}\right]$ mevalonolactone $(5.7 \mathrm{Ci} / \mathrm{mmol})$ were purchased from New England Nuclear, Boston, MA. RS 5[14 $\mathrm{C}]$ mevalonate $(15 \mathrm{mCi} / \mathrm{mmol})$ was purchased from Research Products International Corp., Mt. Prospect, IL. Glucose-6-phosphate dehydrogenase (type XXIII from Leuconostoc mesenteroides), sodium EDTA, and 2-mercaptoethanol were purchased from Sigma Chemical Co., St. Louis, MO. The thin-layer chromatography (TLC) polygram Sil G plates were purchased from Brinkmann Instruments Co., Westbury, NY. Ultrafluor scintillation fluid was purchased from National Diagnostics, Inc., Advanced Applications Institute Inc., Somerville, NJ. Ion exchange resin AG-1-X8, 200400 mesh (formate form) was purchased from Bio-Rad Laboratories, Richmond, CA. Human tumor necrosis factor-alpha with a sp act of 5 $\times 10^{7} \mathrm{U} / \mathrm{mg}$ produced by recombinant DNA techniques was kindly provided by Dr. H. M. Shepard of Genentech Inc., San Francisco, CA.

Animal procedures. Male Sprague-Dawley rats $(200 \mathrm{~g})$ were purchased from Simonsen Animal Vendors, Gilroy, CA. The animals were maintained on a reverse 12 -h light cycle ( 3 a.m. -3 p.m. dark, 3 p.m. -3 a.m. light) and were fed rat chow (Simonson Animal Vendors) and water ad lib. The animals were injected via the tail vein with $25 \mu \mathrm{g}$ of TNF in 0.5 $\mathrm{ml}$ of $0.9 \%$ saline or saline alone. This dose is $\sim$ one-quarter that shown to produce tumor necrosis in vivo (5). In some experiments lower doses of tumor necrosis factor were employed ( 1 or $5 \mu \mathrm{g}$ ). After the injections the animals were fasted.

Lipogenesis in vivo. On the day of the study the rats were injected i.p. with tritiated water $(50 \mathrm{mCi}) .1 \mathrm{~h}$ later the animals were killed, weighed, and a blood specimen obtained. In this study the times shown represent the number of hours after the administration of TNF. Thus, the incorporation of ${ }^{3} \mathrm{H}_{2} \mathrm{O}$ into lipids was studied at $1-2,3-4,6-7 \mathrm{~h}$, and $16-17 \mathrm{~h}$. The tissues indicated were removed (fat tissue was obtained from the epididymal fat pad, and muscle tissue, from the quadriceps 
muscle), individually weighed, and the lipids saponified by refluxing overnight in a solution of $45 \% \mathrm{KOH}$, water, and $70 \%$ ethyl alcohol (2:1:5). Saponification results in the breakdown of complex lipids into their constituents, i.e., triglycerides to fatty acids and glycerol, cholesterol esters to cholesterol and fatty acids, etc. The flasks were cooled and an internal standard of $\left[{ }^{14} \mathrm{C}\right]$ cholesterol and $\left[{ }^{14} \mathrm{C}\right]$ oleic acid was added before extracting the nonsaponifiable material three times with $25 \mathrm{ml}$ of petroleum ether. The petroleum ether extract was dried, dissolved in chloroform, and then applied to TLC plates. The plates were developed in ethyl acetate-benzene (1:5) and the bands corresponding to standards of cholesterol, lanosterol, and squalene were cut from the plate and counted by liquid scintillation. The total nonsaponifiable lipid is the sum of the cholesterol, lanosterol, and squalene bands. The window settings of the scintillation counter were adjusted so that $<0.2 \%$ of the tritium counts were recorded in the ${ }^{14} \mathrm{C}$-window and $\sim 10 \%$ of the ${ }^{14} \mathrm{C}$ counts, in the tritium window. Calculations were corrected for the spillover of tritium and for ${ }^{14} \mathrm{C}$, background, and recovery of the internal standard.

The fatty acids were extracted three times with petroleum ether after acidifying the saponified material to $\mathrm{pH}<2.0$ with concentrated hydrochloric acid. The petroleum ether extract was dried, dissolved in chloroform, and an aliquot counted as described above. The specific activity of the tritiated water was determined individually for each animal by measuring the disintegrations per minute per milliliter of plasma at the end of the experiment and dividing by millimoles of water per milliliter plasma ( $52 \mathrm{mmol} / \mathrm{ml}$ plasma, assuming that plasma is $93 \%$ water). The validity of our methodology for measuring lipid synthesis has been demonstrated in earlier publications $(14,15)$.

Lipogenesis in vitro. Between 9 and 10 a.m. the animals were killed and the liver rapidly removed. $0.5-\mathrm{mm}$ thick slices were prepared with a Mcllwain tissue slicer and $200 \mathrm{mg}$ of tissue was placed in the outer well of a $25-\mathrm{ml}$ center-well flask containing $2 \mathrm{ml}$ of Krebs-Ringer phosphate buffer and either $1\left[{ }^{14} \mathrm{C}\right]$ acetate $(10 \mu \mathrm{Ci} / 10 \mu \mathrm{mol})$ or $\mathrm{RS}$ $5\left[{ }^{14} \mathrm{C}\right]$ mevalonate $(2 \mu \mathrm{Ci} / 262 \mathrm{nmol})$. The flasks were gassed with $95 \%$ $\mathrm{O}_{2} / 5 \% \mathrm{CO}_{2}$ for $15 \mathrm{sec}$, stoppered with serum caps, and incubated for 1 $\mathrm{h}$ at $37^{\circ} \mathrm{C}$ in a Dubnoff metabolic shaker at 100 oscillations/min. At the end of this incubation period, $0.8 \mathrm{ml}$ of $1 \mathrm{~N} \mathrm{NaOH}$ was injected through the serum cap into the center well and $1 \mathrm{ml}$ of $1-\mathrm{N} \mathrm{H}_{2} \mathrm{SO}_{4}$ injected into the outer well. ${ }^{14} \mathrm{CO}_{2}$ was then collected in the inner well by reincubating the samples for $15 \mathrm{~min}$ in the Dubnoff shaker. The incubation flasks were then opened and $0.1 \mathrm{ml}$ of the center-well $\mathrm{NaOH}$ solution was added to scintillation vials containing $10 \mathrm{ml}$ of ultrafluor. The ${ }^{14} \mathrm{C}$ content was determined with a liquid scintillation counter (model LS 330; Beckman Instruments, Inc., Fullerton, CA). All values were corrected for the small amount of ${ }^{14} \mathrm{C}$ recovered from flasks incubated simultaneously with boiled tissues. The tissues were then saponified by refluxing overnight in a solution of $45 \% \mathrm{KOH}$, water, and $70 \%$ ethyl alcohol (2:1:5) and then analyzed for ${ }^{14} \mathrm{C}$ lipids as described above. In these experiments ${ }^{3} \mathrm{H}$ internal standards were employed.

$H M G$ CoA reductase assay. The animals were killed at 9 a.m. and the liver excised. The liver was homogenized in $0.3 \mathrm{M}$ sucrose, $10 \mathrm{mM}$ 2-mercaptoethanol, $10 \mathrm{mM}$ sodium EDTA, and either $50 \mathrm{mM}$ sodium chloride or $50 \mathrm{mM}$ sodium fluoride with a homogenizer (Dounce, made by Kontes Glass Co., Vineland, $\mathrm{NJ})(1 \mathrm{~g} / 3 \mathrm{ml}$ buffer). The homogenate was centrifuged at $10,000 \mathrm{~g}$ for $15 \mathrm{~min}$ at $5^{\circ} \mathrm{C}$ in a centrifuge (model $\mathrm{J}$ $21 \mathrm{~B}$; Beckman Instruments, Inc.). The supernatant was next centrifuged at $100,000 \mathrm{~g}$ for $60 \mathrm{~min}$ at $5^{\circ} \mathrm{C}$ in an ultracentrifuge (model L5-50; Beckman Instruments, Inc.) to sediment microsomes.

HMG CoA reductase activity was determined in the microsomes by incubating 50-200 $\mu \mathrm{g}$ of microsomal protein in a $0.2-\mathrm{ml}$ solution containing $0.1 \mathrm{M}$ potassium phosphate, $20 \mathrm{mM}$ glucose-6-phosphate, 2.5 mM NADP, $12.5 \mathrm{mM}$ dithiothreitol, and $1.2 \mathrm{U}$ of glucose-6-phosphate dehydrogenase ( $\mathrm{pH}$ 7.4). The reaction was initiated by the addition of $3\left[{ }^{14} \mathrm{C}\right] \mathrm{HMG} \mathrm{CoA}$, and then the mixture was incubated at $37^{\circ}$ for $1 \mathrm{~h}$. The reaction was terminated by the addition of $0.01 \mathrm{ml}$ of $10-\mathrm{N} \mathrm{HCl}$, and an internal standard of RS $5\left[{ }^{3} \mathrm{H}\right]$ mevalonate $(\sim 100,000 \mathrm{cpm})$ was added. The acidified reaction mixture was incubated at room temperature for $30 \mathrm{~min}$ to assure lactonization of the mevalonate. The $\left[{ }^{14} \mathrm{C}\right] \mathrm{mevalonate}$ was then separated from HMG CoA on a 5-cm AG-1-X8 resin column. The eluant from the column was counted in ultrafluor scintillation fluid. The gain and discriminator window settings were adjusted so that $<0.2 \%$ of the tritium was counted in the ${ }^{14} \mathrm{C}$ window and $<10 \%$ of the ${ }^{14} \mathrm{C}$ counts were recorded in the ${ }^{3} \mathrm{H}$ window. Counts were corrected for spillover and background. Recovery of the tritiated mevalonate averaged $\sim 60 \%$. Enzyme activity was corrected by subtracting the activity of a zero-time blank. HMG CoA reductase activity was expressed as picomoles mevalonate synthesized per milligram protein per min. Protein was assayed by the method of Bradford (protein assay; Bio-Rad Laboratories).

Cholesterol and triglyceride determinations. Both serum triglyceride, after extraction with Dole's reagent, and serum cholesterol were measured by using diagnostic kit Nos. 405 and 351, respectively (Sigma Chemical Co.).

Statistical differences were determined by using a two-tailed Student's $t$ test.

\section{Results}

Effect of TNF on plasma and liver lipids. The effect of the intravenous administration of TNF $17 \mathrm{~h}$ before study on body and liver weight and plasma and liver lipids is shown in Table I. Hepatic weight was increased $21 \%$ in the animals treated with TNF (control $7.57 \pm 0.13 \mathrm{~g}$ vs. TNF $9.18 \pm 0.20 \mathrm{~g}, P<0.001$ ), but total body weight was unaffected. Additionally, small intestine and skin weight (data not shown) were also not altered by the administration of TNF. Plasma triglyceride concentrations were increased $67 \%$ and the plasma cholesterol levels, $29 \%$ in the animals treated with TNF. Hepatic triglyceride content was increased in the TNF-treated animals but this observation is of borderline statistical significance because of the greater degree of variability in the triglyceride concentration in the animals administered TNF. Free-cholesterol content in the liver was unaffected by TNF administration, but hepatic cholesterol ester content was significantly decreased (control $0.84 \pm 0.12 \mathrm{mg} / \mathrm{g}$ vs. TNF $0.38 \pm 0.05 \mathrm{mg} / \mathrm{g}, P<0.01$ ).

Table I. Effect of TNF on Plasma and Liver Lipids (17 h)

\begin{tabular}{|c|c|c|c|c|c|c|c|}
\hline & \multicolumn{2}{|l|}{ Weight } & \multicolumn{2}{|l|}{ Plasma } & \multicolumn{3}{|l|}{ Liver } \\
\hline & Total body & Liver & Triglycerides & Cholesterol & Triglycerides & Cholesterol & Cholesterol ester \\
\hline & $g$ & $g$ & $m g / d l$ & $m g / d l$ & $m g / g$ & $m g / g$ & $m g / g$ \\
\hline Control & $228 \pm 5.1$ & $7.57 \pm 0.13$ & $39.7 \pm 5.6$ & $69.5 \pm 2.8$ & $0.98 \pm 0.12$ & $3.41 \pm 0.28$ & $0.84 \pm 0.12$ \\
\hline \multirow[t]{2}{*}{ TNF } & $224 \pm 5.1$ & $9.18 \pm 0.20$ & $66.3 \pm 6.8$ & $89.8 \pm 4.3$ & $1.74 \pm 0.38$ & $3.10 \pm 0.30$ & $0.38 \pm 0.05$ \\
\hline & NS & $P<0.001$ & $P<0.01$ & $P<0.001$ & $P<0.1$ & NS & $P<0.01$ \\
\hline
\end{tabular}

$17 \mathrm{~h}$ before study the animáls were injected via the tail vein with $25 \mu \mathrm{g}$ of TNF or saline. After the injection the animals were fasted. Values are means \pm SE. $n=25$ for weights and plasma cholesterol; $n=10$ for liver lipids; $n=19$ for control triglycerides; and $n=18$ for TNF triglycerides. 
Effect of TNF on lipogenesis in vivo. The effect of TNF administration 16-17 h before measurement of the in vivo incorporation of ${ }^{3} \mathrm{H}_{2} \mathrm{O}$ into lipids in a variety of tissues is shown in Table II. As shown in Table II and Fig. 1, the incorporation of ${ }^{3} \mathrm{H}_{2} \mathrm{O}$ into fatty acids, cholesterol, and total nonsaponifiable lipids was increased in the livers of animals treated with TNF. Cholesterol synthesis was increased 2.3-fold, total nonsaponifiable lipid synthesis, 2.2 -fold, and fatty acid synthesis, $35 \%$ in the TNF-treated animals. It should be recognized that the data presented are on a per gram basis. From the point of view of total body lipid homeostasis, total organ synthesis may be of greater significance. Because, as shown in Table I, liver mass was increased after TNF administration, the increase in fatty acid, cholesterol, and total nonsaponifiable synthesis in the TNFtreated animals was even more marked in the liver when expressed on a per organ basis (fatty acids: control $13.0 \pm 0.86 \mu \mathrm{mol}$ vs. TNF $21.8 \pm 1.40 \mu \mathrm{mol}$ incorporated/h per total organ, $67 \%$ increase, $P<0.001$; cholesterol: control $8.3 \pm 1.9 \mu \mathrm{mol}$ incorporated/h per total organ vs. TNF $23.7 \pm 3.5 \mu \mathrm{mol}$ incorporated/ h per total organ, 2.9 -fold increase, $P<0.01$; total nonsaponifiable lipids: control $11.0 \pm 2.6$ vs. TNF $28.3 \pm 4.7 \mu \mathrm{mol}$ incorporated/h per total organ, 2.6 -fold increase $P<0.01$ ).

Table II. Effect of TNF on In Vivo Lipid Synthesis (16-17 h)

\begin{tabular}{|c|c|c|c|}
\hline & Cholesterol & TNS & Fatty acids \\
\hline & $\mu \mathrm{mol}^{*}$ & $\mu \mathrm{mol}^{*}$ & $\mu \mathrm{mol}^{*}$ \\
\hline \multicolumn{4}{|l|}{ Liver } \\
\hline \multirow[t]{2}{*}{ Control $(n=10)$} & $1.06 \pm 0.23$ & $1.39 \pm 0.32$ & $1.82 \pm 0.12$ \\
\hline & $P<0.001$ & $P<0.02$ & $P<0.02$ \\
\hline $\operatorname{TNF}(n=10)$ & $2.49 \pm 0.33$ & $2.99 \pm 0.44$ & $2.45 \pm 0.15$ \\
\hline \multicolumn{4}{|l|}{ Serum } \\
\hline \multirow[t]{2}{*}{ Control $(n=10)$} & $0.036 \pm 0.008$ & $0.059 \pm 0.012$ & $0.090 \pm 0.009$ \\
\hline & $P<0.001$ & $P<0.001$ & NS \\
\hline $\operatorname{TNF}(n=10)$ & $0.159 \pm 0.021$ & $0.222 \pm 0.021$ & $0.101 \pm 0.012$ \\
\hline \multicolumn{4}{|l|}{ Small intestine } \\
\hline \multirow[t]{2}{*}{ Control $(n=5)$} & $0.86 \pm 0.08$ & $1.11 \pm 0.08$ & $5.77 \pm 1.13$ \\
\hline & NS & NS & NS \\
\hline $\operatorname{TNF}(n=5)$ & $0.70 \pm 0.07$ & $0.95 \pm 0.07$ & $5.01 \pm 0.48$ \\
\hline \multicolumn{4}{|l|}{ Adipose } \\
\hline \multirow[t]{2}{*}{ Control $(n=5)$} & $0.041 \pm 0.011$ & $0.078 \pm 0.012$ & $2.11 \pm 0.104$ \\
\hline & NS & NS & NS \\
\hline TNF $(n=5)$ & $0.057 \pm 0.001$ & $0.093 \pm 0.003$ & $2.10 \pm 0.177$ \\
\hline \multicolumn{4}{|l|}{ Muscle } \\
\hline \multirow[t]{2}{*}{ Control $(n=5)$} & $0.020 \pm 0.008$ & $0.033 \pm 0.010$ & $0.220 \pm 0.019$ \\
\hline & NS & NS & NS \\
\hline TNF $(n=5)$ & $0.023 \pm 0.005$ & $0.033 \pm 0.005$ & $0.228 \pm 0.013$ \\
\hline \multicolumn{4}{|l|}{ Skin } \\
\hline \multirow[t]{2}{*}{ Control $(n=5)$} & $0.394 \pm 0.037$ & $1.090 \pm 0.079$ & - \\
\hline & NS & $P<0.05$ & \\
\hline TNF $(n=5)$ & $0.374 \pm 0.008$ & $0.869 \pm 0.048$ & - \\
\hline
\end{tabular}

$16 \mathrm{~h}$ after the intravenous administration of TNF or saline the animals were injected with $50 \mathrm{mCi}$ i.p. of tritiated water. $1 \mathrm{~h}$ later the animals were killed and the tissues indicated were removed, weighed, and individually saponified in a $\mathrm{KOH}-$ ethanol solution. The incorporation of tritiated water into cholesterol, nonsaponifiable lipids, and fatty acids were determined after petroleum ether extraction. Values are means $\pm \mathrm{SE}$; TNS, total nonsaponifiable lipids.

${ }^{*} \mu \mathrm{mol}{ }^{3} \mathrm{H}_{2} \mathrm{O}$ incorporated/g per $\mathrm{h}$.

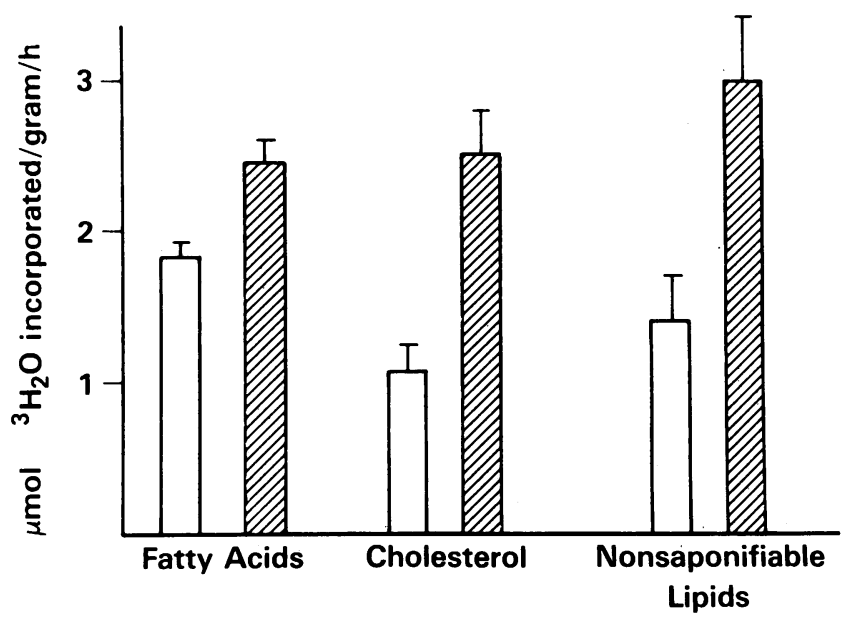

Figure 1. Lipid synthesis in the liver. Values are mean \pm SE. $16 \mathrm{~h}$ after the intravenous administration of TNF or saline the animals were injected with $50 \mathrm{mCi}$ i.p. of tritiated water. $1 \mathrm{~h}$ later the animals were killed and the liver was removed, weighed, and saponified in a $\mathrm{KOH}-$ ethanol solution. The incorporation of tritiated water into cholesterol $(P<0.001)$, nonsaponifiable lipids $(P<0.02)$, and fatty acids $(P$ $<0.02$ ) were determined after petroleum ether extraction. (口) Control $(n=10)$. ( $\square)$ TNF $(n=10)$.

Note, the quantity of labeled cholesterol and total nonsaponifiable lipids in the serum of animals administered TNF was significantly increased (Table II, cholesterol 4.4-fold, total nonsaponifiable lipids 3.8 -fold). This and other laboratories have shown that in short-term ${ }^{3} \mathrm{H}_{2} \mathrm{O}$ labeling studies the quantity of labeled sterols in the serum is reflective of hepatic synthesis (16, 17). Thus, the increase in labeled sterols in the serum reflected the increase in hepatic sterol synthesis. The quantity of labeled fatty acids in the serum was not significantly increased in the TNF-treated animals.

In contrast to the increase in hepatic lipogenesis observed in the TNF-treated animals, the administration of TNF did not stimulate fatty acid, cholesterol, or total nonsaponifiable lipids synthesis in the small intestine, adipose tissue, muscle, or skin (Table II). These results demonstrate that the ability of TNF to stimulate hepatic fatty acid, cholesterol, and total nonsaponifiable lipid synthesis was an effect specifically localized to the liver.

Effect of TNF on in vitro lipogenesis in the liver. The incorporation of acetate into fatty acid, cholesterol, and total nonsaponifiable lipids was measured in liver slices from control and TNF-treated animals (Table III). Fatty acid synthesis was increased 97\%; cholesterol synthesis, 95\%; and total nonsaponifiable lipid synthesis, $74 \%$ in the liver slices prepared from animals administered TNF. In contrast, the metabolism of acetate to $\mathrm{CO}_{2}$ was unaffected in the TNF-treated animals. These results agree with our in vivo observations using ${ }^{3} \mathrm{H}_{2} \mathrm{O}$, and further demonstrate that TNF administration stimulates hepatic lipogenesis.

To localize the site at which TNF increased sterologenesis we measured the incorporation of mevalonate into cholesterol, total nonsaponifiable lipids, and $\mathrm{CO}_{2}$ (via the shunt pathway) in liver slices (Table III). In contrast to our observations using acetate and tritiated water, the incorporation of mevalonate into cholesterol and total nonsaponifiable lipids was not increased in liver slices prepared from animals treated with TNF. This suggests that the stimulation of sterol synthesis in animals treated with TNF was localized to the early steps of sterol synthesis (i.e., 
Table III. Effect of TNF on Lipogenesis in the Liver In Vitro (16 h)

\begin{tabular}{lllll}
\hline & Cholesterol & TNS & Fatty acids & $\mathrm{CO}_{2}$ \\
\hline & $n m l^{*}$ & $n$ nol $^{*}$ & $n m o l^{*}$ & $n m o l^{*}$ \\
Acetate & & & & \\
Control $(n=5)$ & $42.8 \pm 9.5$ & $51.6 \pm 11.6$ & $54.8 \pm 4.4$ & $422.4 \pm 49.8$ \\
& $P<0.01$ & $P<0.05$ & $P<0.001$ & $\mathrm{NS}$ \\
$\operatorname{TNF}(n=5)$ & $83.6 \pm 7.5$ & $89.7 \pm 7.8$ & $108.2 \pm 5.9$ & $517.1 \pm 32.6$ \\
Mevalonate & & & & \\
Control $(n=5)$ & $10.8 \pm 1.7$ & $15.2 \pm 2.1$ & - & $1.44 \pm 0.13$ \\
& $\mathrm{NS}$ & $\mathrm{NS}$ & & $\mathrm{NS}$ \\
$\operatorname{TNF}(n=5)$ & $14.1 \pm 1.0$ & $16.9 \pm 1.0$ & - & $1.39 \pm 0.12$ \\
& & & & \\
\hline
\end{tabular}

$16 \mathrm{~h}$ after the intravenous administration of TNF or saline the animals were killed, and $200 \mathrm{mg}$ of liver slices were placed in center-well flasks containing $2 \mathrm{ml}$ of Krebs-Ringer phosphate buffer and either $1\left[{ }^{14} \mathrm{C}\right]$ acetate $(10 \mu \mathrm{Ci} / 10 \mu \mathrm{mol})$ or $\mathrm{RS} 5\left[{ }^{14} \mathrm{C}\right]$ mevalonate $(2 \mu \mathrm{Ci} / 262$ nmol). The flasks were incubated at $37^{\circ} \mathrm{C}$ for $1 \mathrm{~h}$, after which the incorporation of label into cholesterol, nonsaponifiable lipids, fatty acids, and $\mathrm{CO}_{2}$ was determined. Values are means $\pm \mathrm{SE}$; TNS, total nonsaponifiable lipids.

* nmol incorporated/200 mg tissue per $\mathrm{h}$.

at steps that precede the formation of mevalonate). The hepatic conversion of mevalonate to $\mathrm{CO}_{2}$ via the shunt pathway of mevalonate metabolism was also not affected by TNF administration.

Effect of TNF on hepatic HMG COA reductase activity. The effect of the administration of TNF on hepatic HMG CoA reductase activity, the rate-limiting enzyme in sterologenesis, is shown in Fig. 2. It is well recognized that HMG CoA reductase activity is modulated by a reversible phosphorylation-dephosphorylation with the phosphorylated form of the enzyme being inactive and the dephosphorylated form, active $(18,19)$. During the routine isolation of liver microsomes dephosphorylation (activation) of HMG CoA reductase occurs, and therefore HMG CoA reductase assay performed on these samples represents an index of the total quantity of enzyme present in the tissue. If, however, microsomes are isolated in the presence of fluoride ion, which blocks dephosphorylation, assays of HMG CoA reductase activity are indicative of the quantity of dephosphorylated (active) enzyme in situ. As illustrated in Fig. $2 A$, HMG CoA reductase activity in hepatic microsomes isolated in sodium

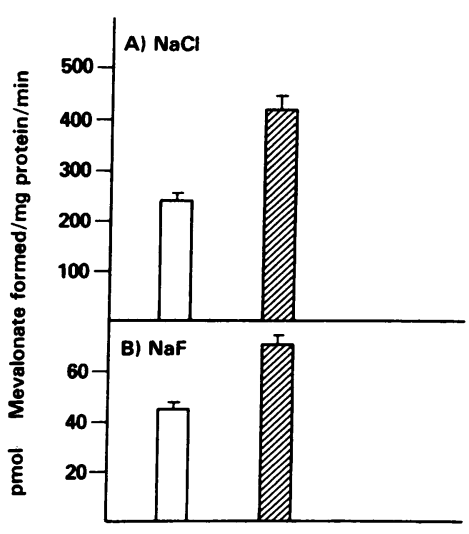

Figure 2. HMG CoA reductase activity in the liver. Values are mean \pm SE. $16 \mathrm{~h}$ after the intravenous administration of TNF or saline the animals were killed and the liver microsomes were isolated by ultracentrifugation in either a $\mathrm{NaCl}$ buffer $(A)$ or $\mathrm{NaF}$ buffer $(B)$. HMG CoA reductase activity was then determined in the hepatic microsomes and was significantly increased in (घ) TNF-treated animals as compared with (D) controls $(P<0.001)$ in both $(A)$ and $(B)$. chloride buffer, which does not block dephosphorylation, was increased $72 \%$ in the animals treated with TNF. Similarly, as shown in Fig. $2 B$, HMG CoA reductase activity in hepatic microsomes isolated in sodium fluoride buffer, which blocks dephosphorylation, was increased $58 \%$ in the animals treated with TNF. The percentage of reductase in the active dephosphorylated form is $18.6 \pm 1.2 \%$ (sodium fluoride divided by sodium chloride) in the control animals and $17.4 \pm 1.1 \%$ in the animals treated with TNF (NS). These results indicate that HMG CoA reductase activity was increased in the liver of animals treated with TNF, and that this increase in activity was probably due to an increase in the quantity of enzyme present and not to a change in the phosphorylation state.

Time course of TNF effects. As shown in Table IV, at 2, 4, and $7 \mathrm{~h}$ after the administration of TNF there was no difference in either total body or hepatic weight between the control and TNF-treated animals. Plasma triglyceride levels were significantly increased in the TNF-treated animals at all time periods studied. In contrast TNF administration increased plasma cholesterol levels only after $7 \mathrm{~h}$ of treatment. Thus, the increase in plasma triglyceride concentration occurred rapidly after the administration of TNF, whereas the increase in plasma cholesterol concentrations required a longer incubation.

The incorporation of ${ }^{3} \mathrm{H}_{2} \mathrm{O}$ into hepatic fatty acids was significantly increased in the TNF-treated animals at 1-2, 3-4, and 6-7 h after TNF administration $(61,69$, and $48 \%$, respectively). In these experiments $25 \mu \mathrm{g}$ of TNF was administered to each animal. An increased incorporation of ${ }^{3} \mathrm{H}_{2} \mathrm{O}$ into hepatic fatty acids at 1-2 h was also observed in animals treated with $5 \mu \mathrm{g}$ of TNF (control $n=4,2.67 \pm 0.21 \mu \mathrm{mol}$ vs. TNF $n=5,4.83 \pm 0.39$ $\mu \mathrm{mol}{ }^{3} \mathrm{H}_{2} \mathrm{O}$ incorporated into fatty acids/h per $\left.\mathrm{g}, P<0.01\right)$. In contrast, the administration of $1 \mu \mathrm{g}$ TNF had no effect on hepatic lipid synthesis (control $n=5,4.81 \pm 0.37 \mu \mathrm{mol}$ vs. TNF $n=5$, $5.19 \pm 0.40 \mu \mathrm{mol}{ }^{3} \mathrm{H}_{2} \mathrm{O}$ incorporated into fatty acids/h per $\mathrm{g}$, NS).

There was a tendency for sterol synthesis to also be increased at these time periods, but the increases did not reach statistical significance (3-4 h, borderline significance $P<0.1)$. In comparison with our 16-17-h experiments described above, the increase in hepatic fatty acid synthesis was greater at these early time periods, whereas the TNF-induced stimulation in sterol synthesis was more pronounced at the later time. Note, at 1-2 $\mathrm{h}$ the quantity of labeled fatty acids in the serum was greatly increased in the TNF-treated animals (control $0.48 \pm 0.08 \mu \mathrm{mol}$ vs. TNF $1.50 \pm 0.40 \mu \mathrm{mol}{ }^{3} \mathrm{H}_{2} \mathrm{O}$ incorporated/h per $\mathrm{ml}$ serum, $P<0.05$ ), whereas the quantity of labeled cholesterol or nonsaponifiable lipids was no different.

The incorporation of acetate into fatty acids, cholesterol, and total nonsaponifiable lipids were measured in liver slices from control and animals administered TNF $90 \mathrm{~min}$ before study (Table V). In agreement with our in vivo studies, fatty acid synthesis was increased $62 \%$ in the TNF-treated animals. Sterol synthesis was also increased, but once again this increase was of only borderline statistical significance. Note, the oxidation of acetate to $\mathrm{CO}_{2}$ was decreased $2 \mathrm{~h}$ after TNF administration.

\section{Discussion}

Infectious diseases frequently result in systemic metabolic changes such as hyperlipidemia (6-8). Cerami and co-workers have demonstrated that TNF inhibits the activity of lipoprotein lipase in cultured adipose cells by decreasing the synthesis of the enzyme (12). Thus, they postulated that during infections, pro- 


\begin{tabular}{|c|c|c|c|c|c|c|c|}
\hline & \multicolumn{2}{|l|}{ Weight } & \multicolumn{2}{|l|}{ Plasma } & \multicolumn{3}{|l|}{ Liver synthesis } \\
\hline & Total body & Liver & Triglycerides & Cholesterol & Fatty acids & Cholesterol & TNS \\
\hline & 8 & 8 & $m g / d l$ & $m g / d l$ & $\mu \mathrm{mol}^{*}$ & $\mu \mathrm{mol}^{*}$ & $\mu \mathrm{mol}^{*}$ \\
\hline \multicolumn{8}{|l|}{$1-2 \mathrm{~h}$} \\
\hline \multirow[t]{2}{*}{ Control $(n=5)$} & $308 \pm 3.8$ & $11.35 \pm 0.24$ & $51.8 \pm 3.6$ & $83 \pm 6.8$ & $3.08 \pm 0.31$ & $1.72 \pm 0.30$ & $2.18 \pm 0.36$ \\
\hline & NS & NS & $P<0.01$ & NS & $P<0.01$ & NS & NS \\
\hline $\operatorname{TNF}(n=5)$ & $306 \pm 10$ & $11.28 \pm 0.75$ & $113.4 \pm 12.9$ & $77 \pm 3.4$ & $4.96 \pm 0.40$ & $2.34 \pm 0.32$ & $2.93 \pm 0.40$ \\
\hline \multicolumn{8}{|l|}{$3-4 h$} \\
\hline \multirow[t]{2}{*}{ Control $(n=5)$} & $232 \pm 4.4$ & $9.40 \pm 0.23$ & $76.4 \pm 8.21$ & $90 \pm 0.4$ & $2.92 \pm 0.16$ & $1.70 \pm 0.29$ & $1.94 \pm 0.33$ \\
\hline & NS & NS & $P<0.02$ & NS & $P<0.001$ & $P<0.1$ & $P<0.1$ \\
\hline TNF $(n=5)$ & $230 \pm 3.8$ & $9.11 \pm 0.19$ & $125 \pm 14.11$ & $91 \pm 5.1$ & $4.93 \pm 0.26$ & $2.75 \pm 0.40$ & $3.13 \pm 0.47$ \\
\hline \multicolumn{8}{|l|}{$6-7 \mathrm{~h}$} \\
\hline \multirow[t]{2}{*}{ Control $(n=10)$} & $225 \pm 2.6$ & $8.33 \pm 0.24$ & $45.2 \pm 2.2$ & $103 \pm 2.6$ & $2.33 \pm 0.10$ & $2.39 \pm 0.26$ & $2.81 \pm 0.31$ \\
\hline & NS & NS & $P<0.01$ & $P<0.001$ & $P<0.01$ & NS & NS \\
\hline TNF & $221 \pm 1.5$ & $8.32 \pm 0.13$ & $75.4 \pm 5.8$ & $134 \pm 4.7$ & $3.44 \pm 0.28$ & $2.65 \pm 0.46$ & $3.12 \pm 0.58$ \\
\hline
\end{tabular}

At the times indicated after the intravenous administration of TNF or saline, the animals were injected i.p. with $50 \mathrm{mCi}$ of tritiated water. $1 \mathrm{~h}$ later the animals were killed and the liver removed, weighed, and saponified in a $\mathrm{KOH}$-ethanol solution. The incorporation of tritiated water into cholesterol, nonsaponifiable lipids, and fatty acids were determined after petroleum ether extraction. Values are means \pm SE; TNS, total nonsaponifiable lipids. * $\mu \mathrm{mol}$ incorporated/g per $\mathrm{h}$.

duction of the cytokine TNF by stimulated macrophages could decrease the clearance of circulating lipoprotein and thereby lead to hyperlipidemia $(20,21)$.

In addition to decreasing lipoprotein lipase activity, TNF has also been shown to inhibit the synthesis of fatty acids in cultured adipocytes by decreasing the activity of acetyl CoA carboxylase and fatty acid synthetase, the key regulatory enzymes involved in fatty acid synthesis $(11,12,23)$. The decrease in activity of these lipogenic enzymes is due to an inhibition of their synthesis, as has also been observed with lipoprotein lipase. In contrast to the inhibition of the enzymes involved in the accumulation of fat, TNF has been shown to increase lipolysis in 3T3-L1 adipocytes by increasing the activity of hormone sensitive lipase $(20,23)$. Thus, TNF both inhibits anabolic lipogenic pathways and stimulates catabolic lipid pathways in adipocytes. It has therefore been proposed that TNF may be responsible for the cachexia and wasting associated with certain systemic infec-

Table V. Effect of TNF on Lipogenesis in the Liver in Vitro (1.5 h)

\begin{tabular}{lllll}
\hline & Cholesterol & TNS & Fatty acids & $\mathrm{CO}_{2}$ \\
\hline & $n m o l^{*}$ & $n m o l^{*}$ & $n m o l^{*}$ & $n$ nol $^{*}$ \\
Control $(n=4)$ & $102 \pm 22$ & $114 \pm 23$ & $44.3 \pm 5.9$ & $548 \pm 18$ \\
TNF $(n=4)$ & $157 \pm 22$ & $179 \pm 22$ & $71.7 \pm 8.1$ & $434 \pm 22$ \\
& NS & $P<0.1$ & $P<0.05$ & $P<0.01$
\end{tabular}

$90 \mathrm{~min}$ after the intravenous administration of TNF or saline the animals were killed and $200 \mathrm{mg}$ of liver slices were placed in center-well flasks containing $2 \mathrm{ml}$ of Krebs-Ringer phosphate buffer and $1\left[{ }^{14} \mathrm{C}\right]$ acetate $(10 \mu \mathrm{Ci} / 10 \mu \mathrm{mol})$. The flasks were incubated at $37^{\circ} \mathrm{C}$ for $1 \mathrm{~h}$, after which the incorporation of label into cholesterol, nonsaponifiable lipids, fatty acids, and $\mathrm{CO}_{2}$ was determined. Values are means \pm SE; TNS, total nonsaponifiable lipids.

* nmol acetate incorporated/200 mg tissue per $h$. tions. It should be recognized, however, that we have shown that other cytokines can have similar effects on lipid metabolism in adipose tissue (23).

Despite the considerable information known on the effect of TNF on adipose tissue, the effect of this cytokine on lipid metabolism in other tissues has not been studied. Acute infections in addition to affecting the catabolism of circulating lipoproteins have also been shown to increase hepatic lipogenesis (6-10). Whether TNF also mediates this central effect was previously unknown. In this study we have for the first time determined the effect of administering recombinant DNA-produced human TNF on lipid metabolism in vivo in rats. After the administration of TNF, plasma triglyceride levels increased very rapidly. $2 \mathrm{~h}$ after TNF treatment, plasma triglyceride concentrations were increased 2.2-fold and remained elevated for at least $17 \mathrm{~h}$ (1.7-fold increase). Plasma cholesterol levels also increased in response to TNF administration. At $17 \mathrm{~h}$ plasma cholesterol levels in the TNF-treated animals were increased 1.3fold $(P<0.001)$. Note, the increase in plasma cholesterol levels was first observed at $7 \mathrm{~h}$ (1.3-fold) after TNF administration and was not observed at earlier time periods ( 2 and $4 \mathrm{~h}$ ). Thus, TNF administration increased both plasma triglyceride and cholesterol levels, but the increase in triglycerides was considerably greater and occurred more rapidly. Studies are in progress to define the lipoprotein distribution of cholesterol and triglycerides in animals administered TNF.

The present study also demonstrates that TNF administration stimulated lipid synthesis in the liver. The incorporation of tritiated water into fatty acids in the liver in vivo was increased 1.6-fold at 1-2 h, 1.7-fold at 3-4 h, 1.5-fold at 6-7 h, and 1.3fold at $16-17 \mathrm{~h}$. Furthermore liver slices from animals treated in vivo with TNF also showed increased fatty acid synthesis. The in vitro incorporation of acetate into fatty acids was increased 1.6-fold at $1.5 \mathrm{~h}$ and 2.0 -fold at $16 \mathrm{~h}$. Thus, TNF administration rapidly stimulated hepatic fatty acid synthesis, and this effect persisted for an extended period of time. Note, in 
other tissues such as the small intestine, adipose tissue, and muscle, TNF administration did not significantly affect fatty acid synthesis. Although we and others have found that TNF decreases fatty acid synthesis in cultured adipose cells $(11,20,23)$, we have not demonstrated a decrease in adipose tissue lipogenesis when rats are treated in vivo under conditions that do lead to increased serum triglycerides.

In addition to the stimulation of hepatic fatty acid synthesis, TNF also enhanced hepatic sterol synthesis. 16-17 h after TNF administration, the incorporation of tritiated water into cholesterol and nonsaponifiable lipids in the liver was increased 2.3fold and 2.2-fold, respectively. In liver slices obtained $16 \mathrm{~h}$ after TNF treatment, the incorporation of acetate into sterols was also increased. In contrast to the effects on hepatic fatty acid synthesis, sterol synthesis was not markedly stimulated soon after TNF treatment. In our 1-2, 3-4, and 6-7 h experiments, we were unable to demonstrate a statistically significant increase in the incorporation of tritiated water into sterols. As we found with fatty acid synthesis, stimulation of sterologenesis by TNF was specifically localized to the liver. No increase in sterol synthesis was seen in the small intestine, adipose tissue, muscle, or skin of TNF-treated animals. Thus, while TNF administration specifically stimulated hepatic sterologenesis, this occurred after an extended period of time as compared with the stimulation of fatty acid synthesis.

Our studies have further shown that the increase in hepatic sterologenesis after TNF administration was localized to the early steps of sterol biosynthesis. The incorporation of mevalonate into cholesterol and nonsaponifiable lipids was not increased in the livers of TNF-treated animals. In contrast, the activity of HMG CoA reductase, the key regulatory enzyme in the cholesterol biosynthetic pathway, was increased after TNF administration. We observed an increase in HMG CoA reductase activity in hepatic microsomes isolated in both sodium chloride (72\% increase) or sodium fluoride buffer (58\% increase). HMG CoA reductase is inactivated by phosphorylation and activated by dephosphorylation $(18,19)$. During the isolation of liver microsomes in sodium chloride buffer, activation of HMG CoA reductase occurred and therefore reductase assays performed in these samples represented an index of the total quantity of enzyme present in the tissue. Isolation of microsomes in sodium fluoride buffers blocked dephosphorylation, and assay of reductase is indicative of the quantity of active enzyme present in the tissue. The finding that HMG CoA reductase activity was increased to a similar extent in microsomes isolated in either a sodium chloride or sodium fluoride buffer after TNF administration suggests that the increase in activity was due to an increased quantity of enzyme present and not to a change in the phosphorylation state.

Whereas the hyperlipidemia that occurrs in infectious disease has been attributed to an inhibition of adipose tissue lipoprotein lipase caused by the release of TNF by stimulated macrophages, the findings of the present study suggest TNF stimulation of hepatic lipid synthesis may also play a role. In support of this is our observation that $1-2 \mathrm{~h}$ after TNF administration the increase in hepatic fatty acid synthesis was accompanied by a 3.1fold increase in the quantity of labeled fatty acids in the serum. Similarly, when hepatic sterol synthesis was maximally increased (16-17 hours), we also observed an increase in the quantity of labeled cholesterol and nonsaponifiable lipids in the serum of the TNF-treated animals after $1 \mathrm{~h}$ of incorporation of label (cholesterol, 4.4-fold increase; nonsaponifiable lipids, 3.8-fold in- crease). Thus, the present study raises the possibility that in addition to decreasing circulating lipoprotein metabolism, TNF also stimulates the production of lipoproteins by the liver, which may contribute to the hyperlipidemia observed in association with infectious diseases.

It should be recognized that the mechanism by which TNF increases hepatic lipid synthesis has not been elucidated by the present study. Whether TNF acts directly on hepatocytes or via inducing the release of other cytokines is unknown. Recent studies have demonstrated that TNF stimulates the production of interleukin $1(24,25)$. We have shown that a variety of cytokines can inhibit adipose tissue lipid metabolism (23) and it is possible that these other cytokines will also affect hepatic lipid synthesis.

In conclusion, our studies demonstrate that the in vivo administration of purified recombinant DNA-produced human TNF can lead to an increase in plasma triglycerides and cholesterol concentrations. Moreover, our studies are the first to demonstrate that TNF stimulates hepatic lipid synthesis. Together with the changes described by others in adipose tissue these effects may represent a coordinate metabolic response to infection. How these alterations in lipid metabolism contribute to the body's host defenses remains to be explored.

\section{Acknowledgments}

We thank Drs. John Patton and H. Michael Shepard of Genentech Inc. for their continued interest in our work. We thank Maggie Joe for the excellent editorial assistance.

This work was supported by grants from the Veterans Administration and the National Institutes of Health (AM-32685 to Kenneth R. Feingold, AM-37102 to Carl Grunfeld). Dr. Feingold and Dr. Grunfeld are the recipients of Clinical Investigator Awards from the Veterans Administration.

\section{References}

1. Buron, S., F. Dianzani, and G. J. Stanton. 1982. The Interferon System: A Review to 1982, Parts I and II. Texas Reports on Biology and Medicine. University of Texas Medical Branch at Galveston, Galveston, Texas. $715 \mathrm{pp}$.

2. 1983. Interleukins, lymphokines, and cytokines. In Proceedings of the Third International Lymphokine Workship. J. J. Oppenheim and S. Cohen, editors. Academic Press, New York. 1-799.

3. Dinarello, C. A., and J. W. Mier. 1986. Interleukins. Annu. Rev. Med. 37:173-178.

4. Old, L. J. 1986. Tumor necrosis factor. Science (Wash. DC). 230: 630-632.

5. Pennica, D., G. E. Nedwin, J. S. Hayflick, P. H. Seeburg, R. Derynck, M. A. Palladino, W. J. Kohr, B. B. Aggarwal, and D. V. Goeddel. 1984. Human tumour necrosis factor. Precursor structure, expression and homology to lymphotoxin. Nature (Lond.). 312:724-729.

6. Beisel, W. R. 1975. Metabolic response to infection. Annu. Rev. Med. 26:9-20.

7. Gallin, J. I., D. Kaye, and W. M. O'Leary. 1969. Serum lipids in infection. N. Engl. J. Med. 281:1081-1086.

8. Fiser, R. H., J. C. Denniston, and W. R. Beisel. 1972. Infection with diplococcus pneumoniae and salmonella typhimurium in monkeys: Changes in plasma lipids and lipoproteins. J. Infect. Dis. 125:54-60.

9. Kaufmann, R. L., C. F. Matson, and W. R. Beisel. 1976. Hypertriglyceridemia produced by endotoxin: role of impaired triglyceride disposal mechanisms. J. Infect. Dis. 133:548-555.

10. Guckian, J. C. 1973. Role of metabolism in pathogenesis of bacteremia due to diplococcus pneumoniae in rabbits. J. Infect. Dis. 127: $1-8$. 
11. Pekala, P. H., M. Kawakami, C. W. Angus, M. D. Lane, and A. Cerami. 1983. Selective inhibition of synthesis of enzymes for de novo fatty acid biosynthesis by an endotoxin-induced mediator from exudate cells. Proc. Natl. Acad. Sci. USA. 80:2743-2747.

12. Kawakami, M., P. H. Pekala, M. D. Lane, and A. Cerami. 1982. Lipoprotein lipase suppression in 3T3-L1 cells by an endotoxin-induced mediator from exudate cells. Proc. Natl. Acad. Sci. USA. 79:912-916.

13. Beutler, B., D. Greenwald, J. D. Hulmes, M. Chang, Y-C. E. Pan, J. Mathison, R. Ulevitch, and A. Cerami. 1986. Identity of tumour necrosis factor and the macrophage-secreted factor cachectin. Nature (Lond.). 316:552-554.

14. Feingold, K. R., M. H. Wiley, G. MacRae, A. H. Moser, S. R. Lear, and M. D. Siperstein. 1982. The effect of diabetes mellitus on sterol synthesis in the intact rat. Diabetes. 31:388-395.

15. Feingold, K. R., M. H. Wiley, G. MacRae, S. R. Lear, G. Zsigmond, and M. D. Siperstein. 1983. De novo sterologenesis in the intact rat. Metabolism. 32:75-81.

16. Dietschy, J. M., and D. K. Spady. 1984. Measurement of rates of cholesterol synthesis using tritiated water. J. Lipid Res. 25:1469-1476.

17. Feingold, K. R., and A. H. Moser. 1985. The effect of lactation on cholesterol synthesis in the intact rat. Am. J. Physiol. 249:G203-208.

18. Gibson, D. M., and T. S. Ingebritsen. 1978. Reversible modulation of liver hydroxymethylglutaryl CoA reductase. Life Sci. 23:2649-2664.

19. Beg, Z. H., and H. B. Brewer Jr. 1981. Regulation of liver 3-
hydroxy-3-methylglutaryl-CoA reductase. Curr. Top. Cell. Regul. 20: 139-184.

20. Pekala, P. H., S. R. Price, C. A. Horn, B. E. Hom, J. Moss, and A. Cerami. 1984. Model for cachexia in chronic disease: secretory products of endotoxin-stimulated macrophages induce a catabolic state in 3T3-L1 adipocytes. Trans. Assoc. Am. Physicians. XCVII:251-259.

21. Beutler, B., and A. Cerami. 1986. Cachectin and tumour necrosis factor as two sides of the same biological coin. Nature (Lond.). 320:584588 .

22. Torti, F. M., B. Dieckmann, B. Beutler, A. Cerami, and G. M. Ringold. 1985. A macrophage factor inhibits adipocyte gene expression: An in vitro model of cachexia. Science (Wash. DC). 229:867-869.

23. Patton, J. S., H. M. Shepard, H. Wilking, G. Lewis, B. B. Aggarwal, T. E. Eessalu, L. A. Gavin, and C. Grunfeld. 1986. Interferons and tumor necrosis factors have similar catabolic effects on 3T3-L1 cells. Proc. Natl. Acad. Sci. USA. 83:8313-8317.

24. Libby, P., J. M. Ordovas, K. R. Auger, A. H. Robbins, L. K. Birinyi, and C. A. Dinarello. 1986. Endotoxin and tumor necrosis factor induce interleukin-1 gene expression in adult human vascular endothelial cells. Am. J. Pathol. 124:179-185.

25. Nawroth, P. P., I. Bank, D. Handley, J. Cassimeris, L. Chess, and D. Stern. 1986. Tumor necrosis factor/cachetin interacts with endothelial cell receptors to induce release of interleukin 1. J. Exp. Med. 163:1363-1375. 